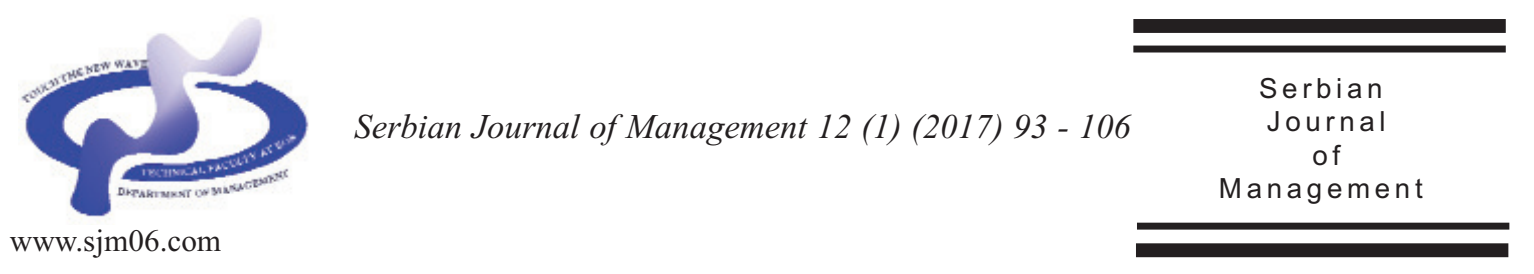

\title{
METHODOLOGICAL APPROACH TO ASSESSMENT OF ORGANIZATIONAL RESOURCES OF THE PRODUCTIVE ACTIVITY
}

\author{
Alexander Miller* \\ Omsk state University named after F. M. Dostoevsky, \\ Department of Economics and financial policy, Prospekt Mira 55A, 644077 Omsk, Russia
}

(Received 11 July 2016; accepted 20 October 2016)

\begin{abstract}
The purpose of this article is to solve the problem connected with development of theoretical and methodological provisions of formation of the assessment procedure of organizational resources of the productive activity.

Theoretical results of our research are: improvement of the concept of development of organizational resources of the productive activity; identifying the impact of organizational resources on the productive activity; justification of the basic principles of formation of the assessment system of efficiency of the organizational resources' use.

Unified methodological approach, was proposed, allowing to combine the complexity of assessment of both quantity of core resources of the productive activity and organizational resources, which significantly develops traditional systems of the productive activity management based on identifying quantitative parameters of the subsystems, their assessment, comparison and analysis.

Also, the opinion was substantiated on assessment of organizational resources' values. It is focused on the development of the productive activity and allows to use the developed tools of the methodological approach for forecast assessment of the impact of the quantity of core resources, used in the productive activity, and organizational resources of the productive activity on the economic results of the enterprise.
\end{abstract}

Keywords: Organizational resources, methodical approach, productive activity, assessment, industry

\section{INTRODUCTION}

In the process of the productive activity the transformation of initial resources into finished products occurs. In this case, a characteristic feature is that, on the one hand, economic indicators of the productive activity are influenced by the quantity of consumed resources; on the other hand, they are influenced by the mechanisms of connecting resources, which form organizational resources of the productive activity. Thus, the problem of quantitative assessment of organizational resources of

\footnotetext{
* Corresponding author: aem55@yandex.ru
}

DOI: $10.5937 /$ sjm12-11357 
industrial enterprises is becoming more relevant.

In this regard, assessment of the changes in economic results, caused not only by changing the number of used resources, but also by changing their organizational parameters and organizational resources of the productive activity, is becoming necessary.

The needs of industrial manufacturing development determine setting the tasks aimed at assessment of the resources' impact. The characteristic features of the such tasks are:

1. Weak formalization of the studied phenomenon, impossibility of full formalization. Due to non-materiality of organizational resources it is extremely difficult to measure their quantity. As a consequence the task, concerned with assessing the impact of organizational resources on the economic results of the productive activity, seems to be even more difficult and complex.

2. The dynamic nature and instability of the studied object. The frequency of the change of the research object values greatly exceeds the frequency of fixation of information by the user. In this regard, in the interval between the first and subsequent values of the recorded resulting parameter, a repeated change of values of the determining factor may occur.

3. Multifactorality of the studied activity. In the evaluation process while simulating the productive process, a huge number of factors, which can be ignored because of their quantity and, consequently, their insignificance, are distinguished. However, this insignificance is a moment value. In the process of the productive activity implementation, the importance of individual factors (including insignificant factors in the previous period) can vary.

Thus, there is a need for an approach that, first, would take into account the above mentioned features of the productive activity and, second, would allow to assess and use organizational resources of enterprises most accurately. In addition, assessment of organizational resources of the productive activity actualizes the need to address a number of factors, each of which creates a special effect on the industrial enterprise.

\section{THEORETICAL STUDIES}

The formation of the assessment procedures of organizational resources of the productive activity includes:

- development of a concept for the development of organizational resources of the productive activity that should be based on the company's strategic objectives. It should also take into account a unified technical and technological development policy on the development of the productive process, with identification of priorities;

- search of assessment tools for organizational resources of the productive activity;

- development of a system of organizational measures that contribute to the development of the industrial enterprise as an industrial structure;

- development of infrastructure of organizational resources of the productive activity considering the specifics of industry conditions, etc.

\subsection{The concept of organizational resources' development}

The concept of development of organizational resources of the productive 
activity should reflect the process of regulation of the productive process, representing a chain of actions aimed at the productive activity for the purpose of quantitative and qualitative changes of industrial enterprises in general.

Prerequisites for the development of the productive activity, based on the capabilities of organizational resources, are:

- prioritization of the enterprise development based on organizational resources of the productive activity;

- availability of some mechanisms and levers of impact on the development of organizational resources at the enterprise;

- availability of certain potential of substantive and organizational resources of the industrial enterprise.

The impact of organizational resources of the productive activity on economic results is carried out by:

- determining the parameters of economic policy in the field of development of the productive activity;

- maneuvering the organizational parameters of core resources (turnover, structure, renewability, etc.);

- using an economic-administrative mechanism of the productive activity development;

- creating an infrastructure of organizational resources of the productive activity and determining the peculiarities of its construction;

- informational impact and support of the processes of the productive activity development.

As a result of using the capabilities of organizational resources of the productive activity the enterprise is developed and the conditions for its development, in the direction to the maximum extent appropriate to the interests of this enterprise, are created.

\subsection{Features of organizational} resources

To meet the needs of the industrial enterprise by assessing and using the impact of organizational resources of the productive activity one should take into account the following features:

- specific capabilities of the enterprise compared to the other enterprises;

- competitive advantages of the enterprise and its products compared to similar enterprises in the industry.

For assessing and using the impact of organizational resources of the productive activity of the enterprise, it is necessary to know the state of organizational resources, the degree of the potential for meeting the needs with their help and the results of such needs' meeting (Kalachanov et al., 2016; Polyushko Yu., 2016). Knowing the state of the problem, the needs of production and its resource capabilities, it is possible to select recommendations on directions for the use of organizational resources' capabilities.

The productive activity, as well as the change and regulation of its parameters are a complex multistep process, therefore, adherence to a unified methodology and compliance with the fundamental principles of a unified system are extremely important. Integration of methods of assessing the impact and use of organizational resources with existing processes of planning, organization, and analysis of the enterprise is determined at the stage of forming the purposes of assessing the impact of organizational resources of the productive activity. The principles and standard indicators, reflecting the results of the impact of the implemented effects on the productive activity, are also determined at this stage.

Policy development in the field of 
assessment and use of the impact of organizational resources of the productive activity is aimed at establishing a set of rules and principles in accordance with which the process of changes of the productive activity at the enterprise occurs. It includes the development of regulations which describe ongoing processes and their quantitative assessment and interpretations in detail. It might be analytical methods or methods of expert estimations. After determining the methods for quantitative assessments, the ranges of parameters' variation are also determined and the targeted boundaries, which may be different for managers of different levels and are determined by the level of their authority on making independent decisions, are set.

\subsection{The fundamental principles}

The formation of the system of assessing organizational resources of the productive activity should be based on a number of fundamental principles:

- the principle of consistency. It consists in considering the system as the chain of elements that form it;

- the principle of complexity. It involves aggregate consideration of all aspects of assessment of organizational resources;

- the principle of integrity. According to this principle, the system is considered as a whole;

- the principle of structure and hierarchy. It implies taking into account existing organizational structures and hierarchies;

- the principle of plurality. This principle implies the existence of multiplicity of solutions and models to describe individual elements and the system as a whole;

- the principle of target orientation. Its essence consists in the fixation of objectives in the field of the productive activity development.

The objects of assessment are indicators which, on the one hand, reflect the activities of production units of productive enterprises within the economic subsystems of the means of labor, labor resources and objects of labor; on the other hand, they characterize economic results of the productive activity of enterprises directly (Khomitskiy, 2013).

Thus, the principle of comprehensive consideration of the productive activity allows us to highlight three major groups of resources: capital resources (expressed by the means of labour), human resources (expressed by the plant personnel) and material resources (expressed in terms of objects of labor).

Assessment and use of organizational resources of the enterprise involve simultaneous consideration of changes in the productive activity from two perspectives: on the one hand, evaluation of changes of organizational parameters of core resources, reflecting the organizational resources, takes place; on the other hand, the changes of economic results of the productive activity of the enterprise are also assessed. This assumes the use of organizational resources both at the enterprise level in general and at the level of individual resource groups in particular.

Considering the enterprise as a complex dynamic structure, in addition to internal factors interacting with external environment, one should take into account the objective uncertainty of attainability of given targets in the initially identified parameters. This factor is not mitigated by the improvements of the system of planning of assessment and analysis of the objects. Accordingly, one of the ways of improving the system of assessment and use of the 
impact of organizational resources of the productive activity on the economic results of enterprises will be starting this process and increasing frequency of its feedback (Klimuk \& Khodos, 2016; Struchkova, 2015). At the same time the principle of unity of the productive system should be respected. It means that the processes of supply, production and sales of products should be linked together and the change of organizational resources in one of the processes should affect other processes, taking into account market demand and production capacity of the enterprise.

The formation of a system of assessing the impact of organizational resources of the productive activity, allowing to transform organizational resource into a responsive state, consists of a sequence of actions:

1. Clarification of the strategic goals of the enterprise.

2. Identification of tasks requiring rapid decisions on the basis of selected indicators.

3. Formation of the current resource and organizational structure of the enterprise.

4. Determination of indicators.

5. Introduction of the system of indicators.

Thus, the use of organizational resources in the productive activity is necessary for industrial enterprises to overcome the problems hindering their development in a highly competitive environment.

\section{METHODOLOGY}

\subsection{Research methods}

In the process of the productive activity industrial enterprises purposefully develop and implement the complex of measures oriented on improvement of forms and methods of assessment of organizational resources of the productive activity that have a significant impact on the economic results. The developed activities are aimed at creation and introduction in industrial practice such assessment system that will increase the interest of enterprises in the rational and efficient use of all available resources, which in turn, will affect economic results.

The production process is carried out in a temporary time interval. Therefore, all calculations shall be made taking into account this time interval. Herewith, this time interval will include the changes in time, and the factors that can not be directly taken into account in the used model.

The main requirement for the measured objects is their constancy and invariance in the measurement process. It is rather difficult to speak about such constancy in economic reality. One can only speak about relative constancy of measurement units within a certain period of time. Such variations of measurement objects lead to the fact that the results of the calculations are valid within narrow limits of time. Therefore, different economic indicators are only comparable if they share a common calculation method.

Since the results of economic calculations are used for decision making in the productive activity, calculation errors can lead to serious losses and reduce economic efficiency.

All this leads to the need to streamline the assessment of organizational resources of the productive activity and the use of a unified methodological basis.

Traditional systems of the productive activity management are based on identifying quantitative parameters of subsystems, their assessment, comparison 
and analysis. In this connection, we face a problem of creating a unified methodological approach that would incorporate the complexity of assessment both of the amount of core resources and organizational resources.

The form, integrating a comprehensive assessment of the resource components of the productive activity, may be represented by a passport of resources of the productive activity of the enterprise. The formation of assessment of the impact of organizational resources of the productive activity on economic results of enterprises involves several stages, each of which corresponds to its own requirements.

The first stage is connected with determining the form of expression of assessment of organizational resources of the productive activity of the enterprise. The second stage is concerned with identification of the factors influencing, organizational resources, and determination of character of interrelation of these factors influencing organizational resources. The third stage is assessment of the impact of organizational resources of the productive activity on the main technical and economic indicators of the enterprise. The fourth stage is represented by assessment of the economic consequences of the use of organizational resources of the productive activity of the enterprise.

The first stage is characterized by the formation of the study as well as determination of the form of expression of assessment of organizational resources of the enterprise operations. The most convenient form for these purposes is a passport of resources of the productive activity of the enterprise which will show the value of indicators of organizational resources in the base period, in the reporting period, and indicators of change (increase or decrease) of these indicators in these periods.

In addition, the passport of resources of the productive activity of the enterprise has a number of advantages compared to other forms of expression: on the one hand, it allows to take into account the share of the impact of each organizational resource on economic performance, on the other hand, it allows to track the features of changes of these indicators in any period of time.

\subsection{Research analytics}

Research analytics determines the content of the second stage, in which a determination of two components of the assessment procedure is made. They are: factors, influencing organizational resources, and determination of the nature of the relationship of these factors. This step is realized by constructing a functional model, suitable for the purposes of assessment of the impact of organizational resource on the economic results of the productive activity of enterprises. The universality of the approach is connected with the fact that it assumes the technical ability to use any functional dependency which is determined by valid economic laws. However, taking into account our task and its productive aspect, it seems to be the most adequate to use the productive function of Cobb-Douglas or its neoclassical interpretation. The studies of such foreign scientists as Black S., Bloom N., Van Reen J., Daum J., Farooqui S., Haskell $\mathrm{J}$. in the field of economic modeling on the basis of neoclassical productive function show the possibility of quantitative assessment of the degree of the resources' impact (including organizational recourses) on the economic results of the productive activity (Black, 2005; Bloom et al., 2011; 
Farooqui, 2005; Haskel, 2016).

A general view of this model is represented by the formula (1):

$Q=A \prod_{j=1}^{n} X_{j}^{y_{j}}$

where:

$Q$ - production volume,

$A$ - aggregate performance of the production factors, which characterizes technological and organizational levels of production,

$X_{j}$ - factors of production, essential for the analysis of output and significant for management,

$y_{j}$ - coefficients of elasticity of output volume by factors of production,

$j-$ amount of allocated in the model factors of production.

However, such solution to quantitative assessment of the impact of organizational resources on the economic results of the productive activity seems to be insufficient due to several reasons. Firstly, due to the non-complexity (organizational resources in the received model are not fully covered due to the lack of a unified methodological basis of core resources decomposition); secondly, because of incomplete accounting of existing factors of production (obviously, distribution on the indices of two factors is insufficient and it is necessary to consider their greater number for more accurate determination of the degree of influence of the respective factor on economic results); thirdly, these parameters are somewhat detached from the real productive activity: modern industrial enterprises do not operate in their operational and accounting systems in the coordinate system of "work - intermediate goods - capital" (instead, there is production of finished products, the volume of sales, fixed and circulating assets, materials, labor compensation fund, the average number of employees, etc.); fourthly, the difference of the original data used for the econometric estimates of the received models implies the possibility of using only methodological basis of the research results of these scientists with subsequent assessment of econometric parameters of the model on unified economic data.

In accordance with the concept of three basic resources: capital, labor and material resources, as well as taking into account the inevitability of unaccounted factors and random statistical deviations, the expression of neoclassical production function should look like this:

$$
Q=A \times L^{y_{L}} \times M^{y_{M}} \times K^{y_{K}} \times \varepsilon
$$

where:

$Q$ - volume of production of goods and services of the enterprise,

$M$ - material resources,

$K$ - capital resources,

$L$ - labour resources,

$\varepsilon$ - random deviation,

$y_{K, L, M}-$ coefficients of elasticity of production volume by relevant resources.

The complexity of assessment of organizational resources can be provided by the following methodical approach:

1) Taking into accounting core resources (labor, intermediate product, capital).

2) Taking into account random deviations and the probability of statistical errors.

3) Decomposition of resources into component parts: the quantitative indicator of core resource and components of organizational resource: the indicator of 
structure and the indicator of dynamics.

4) Modifying the indicators of the theoretical model into the indicators used in the actual production of the enterprise.

Thus, it is possible to obtain a multivariate model of assessment of the resources' impact on the economic results of the productive activity of the enterprises, which will include organizational resources:

$$
Q=F(K ; L ; M) \rightarrow Y=F\left(f X^{X i}\left(X_{i} ; d_{X i} ; \phi_{X i}\right)\right)
$$

where:

$Q$ - production volume,

$F$ - functional relationship between the resources,

$K$ - capital resources,

$L$ - labour resources,

$M$ - material resources,

$f$ - functional relationship between decomposed elements of the i-factor of production $(K, L$ or $M)$,

$X$ - resource (factor of production), a quantitative component,

$d$ - structural component of the resource $\mathrm{X}$.

$\phi$-dynamic component of the resource.

The resulting formula obtained as a result of these transformations is presented below:

$\operatorname{Ln} Q=1 /\left(1-\gamma_{L}\right) \operatorname{Ln} A+\gamma_{K} /\left(1-\gamma_{L}\right) \operatorname{Ln}((Q / K)+$ $\left.\gamma_{K} /\left(1-\gamma_{L}\right) \operatorname{Ln}\left(\Sigma d_{j} \times K_{j}\right)\right)+\gamma_{K} /\left(1-\gamma_{L}\right) \operatorname{Ln}(K / Q)+$ $\gamma_{L} /\left(1-\gamma_{L}\right) \operatorname{Ln}(Q / T)+\gamma_{L} /\left(1-\gamma_{L}\right) \operatorname{Ln}\left(\sum d_{j} \times W_{j}\right)+$ $\gamma_{L} /\left(1-\gamma_{L}\right) \operatorname{Ln}\left(T / \Sigma W_{i}\right)+\gamma_{M} /\left(1-\gamma_{L}\right) \operatorname{Ln}(Q / M)+$ $\gamma_{M} /\left(1-\gamma_{L}\right) \operatorname{Ln}\left(\Sigma d^{\left.M_{j} \times M\right)}+\gamma_{L} /\left(1-\gamma_{L}\right) \operatorname{Ln}(M / Q)+\right.$ $1 /\left(1-\gamma_{L}\right) \operatorname{Ln}(\varepsilon)$

where:

$\left[\gamma_{K} \wedge \gamma_{L} \wedge \gamma_{M}\right] /\left(1-\gamma_{L}\right)$ - coefficients of elasticity of organizational resources by core resources,
$Q / K$ - turnover of non-current assets,

$d_{j}^{k} \times K_{j}-$ structure of non-current assets on the basis of $k$ ( $j$ - is a serial number of selected items non-current assets),

$Q / T$ - labour productivity,

$\Sigma d_{j}{ }_{j} \times W_{j}$ - personnel structure on the basis of $L(j-$ is an ordinal number of the selected structural groups),

$Q / M$ - turnover of current assets,

$\Sigma d^{M}{ }_{j} \times M$ - structure of current assets on the basis of $M(j-$ is serial number of the selected types of current assets).

\section{RESULTS}

\subsection{Assessment of the importance of organizational resources}

Assessment of the impact of organizational resources of the productive activity on the main technical and economic indicators of the enterprise is the content of the third stage. This assessment is carried out using a quasi-Newton method by means of the special application STATISTICA. QuasiNewton method computes the values of the function at different points, assessing by the first and the second derivatives. This data are used for determining the direction of the parameters' changes and minimizing the loss function. The least squares function was used as a loss function (squares minimization of the difference between the observed and calculated values of the function).

Thus, the assessment of unknown coefficients for a sample of 98 industrial enterprises of Russia and three individual companies: LLC "OZG", LLC "Visma" and LLC "Innovative Technology" was made. The results are shown in Table 1.

These results are valid if the achieved 
Table 1. The values of the assessed factors of the impact of organizational resources by core resources of enterprises

\begin{tabular}{|c|c|c|c|c|}
\hline \multirow[b]{2}{*}{ Indicator } & \multicolumn{4}{|c|}{ Indicator value for } \\
\hline & $\begin{array}{l}\text { A sample } \\
\text { of } 98 \\
\text { enter- } \\
\text { prises }\end{array}$ & $\begin{array}{l}\text { LLC } \\
\text { "OZG" }\end{array}$ & $\begin{array}{l}\text { LLC } \\
\text { "Visma" }\end{array}$ & $\begin{array}{l}\text { LLC } \\
\text { "Innovative } \\
\text { Technology" }\end{array}$ \\
\hline \multicolumn{5}{|l|}{$\begin{array}{l}\text { Organizational components of capital } \\
\text { resources }\end{array}$} \\
\hline dynamics of capital resources & 0.21 & 0.15 & 0.25 & 0.28 \\
\hline \multicolumn{5}{|l|}{ the structure of capital resources } \\
\hline $\begin{array}{l}\text { the share of fixed assets in the structure of } \\
\text { non-current assets }\end{array}$ & 0.209 & 0.15 & 0.25 & 0.25 \\
\hline $\begin{array}{l}\text { the share of intangible assets in the structure } \\
\text { of non-current assets }\end{array}$ & 0.001 & 0 & 0 & 0.03 \\
\hline \multicolumn{5}{|l|}{$\begin{array}{l}\text { Organizational components of labor } \\
\text { resources }\end{array}$} \\
\hline labour dynamics & 0.84 & 0.92 & 0.77 & 0.55 \\
\hline $\begin{array}{l}\text { the structure of the labor force } \\
\text { the share of low-skilled workers }\end{array}$ & 0.14 & 0.45 & 0.2 & 0 \\
\hline $\begin{array}{l}\text { the share of workers with medium-low } \\
\text { qualifications }\end{array}$ & 0.06 & 0.05 & 0,25 & 0,2 \\
\hline $\begin{array}{l}\text { the share of workers with medium-high } \\
\text { qualifications }\end{array}$ & 0.14 & 0.22 & 0.25 & 0.15 \\
\hline the share of highly qualified personnel & 0.49 & 0.20 & 0.07 & 0,2 \\
\hline \multicolumn{5}{|l|}{$\begin{array}{l}\text { Organizational components of material } \\
\text { resources }\end{array}$} \\
\hline dynamics of material resources & 0,49 & 0.58 & 0.51 & 0.46 \\
\hline the structure of the material resources & & & & \\
\hline $\begin{array}{l}\text { the share of stocks in the structure of current } \\
\text { assets }\end{array}$ & 0.23 & 0.25 & 0.18 & 0.15 \\
\hline $\begin{array}{l}\text { the share of construction in progress to the } \\
\text { structure of current assets }\end{array}$ & 0.27 & 0.33 & 0.32 & 0.30 \\
\hline $\begin{array}{l}\text { the share of other current assets in the } \\
\text { structure of currents assets }\end{array}$ & 0.01 & 0 & 0.01 & 0.01 \\
\hline
\end{tabular}

Source: Authors' research

significance level ( $\mathrm{p}$-value) equals 0.03 .

The values in the table show the change of the final indicator (the finished products) while assessing the estimated factor by $1 \%$. The nature of the received coefficients meets the criteria for expanded production.

A quick analysis of the results of evaluations, given in table 1 , shows their structural similarity. The obtained data show that indicators of organizational components of labor resources have the greatest value. This can be explained by greater flexibility and specific characteristics of labour resources in comparison with others. In addition, one may notice greater value of capital resources at more technological enterprises and lower value of organizational resources of labor and material resources.

The examples of the calculation of the cumulative effects of organizational 
Table 2. Assessment of the aggregate impact of organizational resources on output, \%

\begin{tabular}{ccc}
\hline LLC "OZG" & LLC "Visma" & LLC "Innovative Technology" \\
\hline 3.30 & 3.06 & 2.58 \\
\hline
\end{tabular}

Source: Authors' research

resources are rather enlightening.

So, we received the following aggregated coefficients of the impact of organizational resources on the economic results of the production (Table 2).

These coefficients show the aggregate coefficient of the production elasticity by organizational resources. It means that if the aggregate change of organizational resources is $1 \%$, the volume of output will change by $3.3 \%$ (for LLC "OZG"), 3,06\% (LLC "Visma") and by $2.58 \%$ (for LLC "Innovative technology").

\subsection{Assessment of the productive activity development}

Assessment of the economic consequences of the use of organizational resources of the productive activity is performed at the fourth stage.
While determining the planned growth of production volumes, one can determine the factors of this growth. One can identify the following factors of this indicator increase: price factor (associated with inflationary processes in the economy, the rise of prices for resources), quantitative factor (connected with changes in the number of used resources) and organizational factor (affects neither prices nor the amount of used resources, but shows the intensity of use and the structure of core resources).

Accordingly, to determine policy directions, it is necessary to clear the impact of the first two factors for the selected enterprises (table 3).

Quantitative indicators in the limit version will have directly proportional value for the production results, expressed in terms of the production output. While maintaining the performance values for labor, equipment

Table 3. Production volume of enterprises in planned and given prices, mln.rub.

\begin{tabular}{|c|c|c|c|}
\hline Indicators & LLC "OZG" & LLC "Visma" & $\begin{array}{l}\text { LLC "Innovative } \\
\text { Technology" }\end{array}$ \\
\hline \multicolumn{4}{|c|}{ Production volume in current prices } \\
\hline Production volume in 2010 & 80.40 & 152.10 & 210.90 \\
\hline Production volume in 2011 & 92.30 & 163.70 & 234.20 \\
\hline Production volume in 2012 & 108.10 & 180.50 & 244.80 \\
\hline Production volume in 2013 (plan) & 130.00 & 205.00 & 270.00 \\
\hline Production volume in 2014 & 155.00 & 233.00 & 297.00 \\
\hline Production volume in 2015 & 185.00 & 265.00 & 326.00 \\
\hline \multicolumn{4}{|c|}{ Production volume in given prices } \\
\hline Production volume in 2010 & 80.40 & 152.10 & 210.90 \\
\hline Production volume in 2011 & 87.08 & 154.43 & 220.94 \\
\hline Production volume in 2012 & 96.21 & 160.64 & 217.87 \\
\hline Production volume in 2013 (plan) & 109.15 & 172.12 & 226.70 \\
\hline Production volume in 2014 & 122.77 & 184.56 & 235.25 \\
\hline Production volume in 2015 & 138.24 & 198.02 & 243.61 \\
\hline
\end{tabular}


and regulations on the use of the materials, the complex impact of quantitative factors will tend to 1 in the limit case.

That is $1 \%$ of the aggregate change in the quantitative factor will account for $1 \%$ of the change in production volume. However, the law of diminishing marginal return of resources will steadily lead to a decrease of this indicator below 1 when the production scale is increased.

Assessment of the aggregate impact of quantitative components on the basis of the neoclassical model of the productive function gives the following results for the enterprises under study (table 4).

By analogy with assessment of organizational resources, evaluation of the impact of quantitative parameters of the productive activity resources is expressed by aggregated coefficients of the production elasticity. It means that when the aggregate change in the number of used resources is changed by $1 \%$, the volume of the production output will be affected by $0.9 \%$ (for LLC "OZG"), by $0.86 \%$ (LLC "Visma") and by $0.78 \%$ (LLC "Innovative technology").

It can be also noted that the observed characteristics of the productive activity is higher if production reserves of the enterprise are higher. When approaching the limits of productive capacities the coefficient declines sharply.

In the process of the productive activity development the main directions of activity of the enterprise and its divisions are determined. Let's compare the efficiency of the impact of organizational resources and quantitative changes of core resources of the enterprise on the economic results in the planned and projected periods. To do this, we should determine the growth of the given production output for the companies under examination (table. 5).

These indicators of the production volume growth exclude the effect of price fluctuations, and, thus, can be used for further assessment of the impact of the quantity of core resources, used in the productive activity, and organizational resources of the productive activity of the enterprise. The comparative analysis is presented in table 6 .

The table shows chain coefficients of the required growth by years of the aggregate quantity of resources and organizational resources for the enterprises under study. It is obvious that to achieve the same results

Table 4. Assessment of the aggregate impact of the quantitative parameters of resources on the results of the productive activity of enterprises, \%

\begin{tabular}{ccc}
\hline LLC "OZG" & LLC "Visma" & LLC "Innovative Technology" \\
\hline 0.90 & 0.86 & 0.78 \\
\hline
\end{tabular}

Source: Authors' research

Table 5. Forecast of the growth of the given production volume

\begin{tabular}{lccc}
\hline \multirow{2}{*}{\multicolumn{1}{c}{ Enterprises }} & \multicolumn{3}{c}{ Increase in production output } \\
\cline { 2 - 4 } & $\mathbf{2 0 1 3}$ to 2012 & $\mathbf{2 0 1 4}$ to 2013 & $\mathbf{2 0 1 5}$ to 2014 \\
\hline LLC "OZG" & 0.135 & 0.125 & 0.126 \\
LLC "Visma" & 0.071 & 0.072 & 0.073 \\
LLC "Innovative Technology" & 0.041 & 0.038 & 0.036 \\
\hline
\end{tabular}

Source: Authors' research 
quantitative parameters should be changed more than in 3 times stronger compared to organizational resources. This is caused by a higher degree of the production elasticity of organizational resource in comparison with the number of core resources.

Accordingly, the issue about the replacement of core resources by organizational resources arises. The impact of this substitution is presented in table 7 .

It is obvious that it is economically feasible to focus efforts on the intensification of the use of existing resources and the search for their optimal structures instead of additional use of resources. The calculated effects are based on the existing experience of enterprises in changing organizational characteristics and, consequently, production volumes as a response to these changes.

One should also pay attention to the impact of non-productive factors on the production output; in particular, these include the following: execution of work in overtime, payment of excess wages, loss of working time (downtime, sick leaves, etc.).

The application area of assessment of the impact of organizational resources on the productive activity of the enterprise can be

Table 6. Forecast assessment of necessary changes of organizational resources and the quantity of resources to perform plan production indicators, $\%$

\begin{tabular}{llll}
\hline Indicators & $\begin{array}{l}\text { LLC } \\
\text { "OZG" }\end{array}$ & $\begin{array}{l}\text { LLC } \\
\text { "Visma" }\end{array}$ & $\begin{array}{l}\text { LLC "Innovative } \\
\text { Technology" }\end{array}$ \\
\hline $\begin{array}{l}\text { Assessment of the aggregate impact of } \\
\text { organizational resources on the production } \\
\text { output }\end{array}$ & 3.30 & 3.06 & 2.58 \\
$\begin{array}{l}\text { Assessment of the aggregate impact of the } \\
\text { quantity of resources on the production output }\end{array}$ & 0.90 & 0.86 & 0.78 \\
$\begin{array}{l}\text { The required aggregate change in the } \\
\text { organizational resources to reach the planned } \\
\text { level of production }\end{array}$ & & \\
$\quad$ in 2013 & 4.08 & 2.33 & 1.57 \\
$\quad$ in 2014 & 3.78 & 2.36 & 1.46 \\
$\quad$ in 2015 & 3.82 & 2.38 & 1.38 \\
$\begin{array}{l}\text { The required aggregate change in the quantity } \\
\text { of resources to reach the planned level of } \\
\text { production }\end{array}$ & & & \\
$\quad$ in 2013 & & & \\
in 2014 & 14.95 & 8.31 & 5.19 \\
$\quad$ in 2015 & 13.87 & 8.40 & 4.84 \\
\hline
\end{tabular}

Source: Authors' research

Table 7. Forecast assessment of relative savings when replacing quantitative factors of growth of the production volume by organizational resources in planned prices, mln.rub.

\begin{tabular}{llll}
\hline \multirow{2}{*}{ Enterprises } & \multicolumn{3}{c}{ Years } \\
\cline { 2 - 4 } & $\mathbf{2 0 1 3}$ & $\mathbf{2 0 1 4}$ & $\mathbf{2 0 1 5}$ \\
\hline LLC "OZG" & 11.86 & 12.38 & 14.07 \\
LLC "Visma" & 10.28 & 11.15 & 12.08 \\
LLC "Innovative Technology" & 8.21 & 7.94 & 7.74 \\
\hline
\end{tabular}

Source: Authors' research 
both at the level of individual enterprise, on the basis of the analysis of dynamic indicators for the reporting-accounting periods in the context of its production units, and at the level of groups of similar enterprises and industries.

\section{CONCLUSION}

Thus, it should be stated that assessment of organizational resources of the productive activity of enterprises and the impact of resources on the economic results of this activity is not linear. The relationship between the elements of organizational resources and the results of the productive activity are complex and involve many factors. Control impacts and processes, occurring in the external environment, which cannot be accounted for within the model, are of great importance. These factors should be taken into account in the production process and additionally in the process of monitoring of the external and internal environment of the enterprise. Herewith, obligatory adjustment of all parameters of the operation and planning of the final results of the productive activity of industrial enterprises should be carried out during this time.

\section{Acknowledgement}

The work is financially supported by the Ministry of education and science of the Russian Federation, within the framework of state assignment to Universities in carrying out scientific research for 2014-2016, project No. 2378.

\section{References}

Black, S. (2005). Measuring organizational capital in the new economy, IZA discussion paper No 1524. B.: Institute for the study of labor, 15 .

Bloom, N., Genakos, C., Sadun, R., \& Van Reen, J. (2011). Management Practices Across Firms and Countries, Harvard Business School, 53.

Farooqui, S. (2005). Information and Communication Technology use and productivity. Economic Trends, 625, 65-74.

Haskel, J. (2016). Do Poor Countries Catch Up to Rich Countries? Review Article on Productivity Convergence: Theory and Evidence by Edward Wolff. International Productivity Monitor, 30, 111-117.

Kalachanov, V.D., Novikov, A.N., Kalachanov, V.V., \& Pronkin, N.N. (2016). The development of the comprehensive system of criteria for optimizing the production activity funding at industrial enterprises (as exemplified by aircraft construction). Organizer of production, 70 (3), 50-61. (in Russian)

Khomitskiy, A.A. (2013). Theoretical aspects of formation and development of the organizational resource at enterprise, Herald of Omsk University. Series «Economics», 2, 97-102. (in Russian)

Klimuk, V.V, \& Khodos, D.V. (2016). Assessment of resource efficiency production of the company, Social and economic and humanitarian magazine, 3, 3-9. (in Russian)

Polyushko, Yu. (2016) Assessment of production activities of the organization, Problems of management, 9 (1), 67-75. (in Russian)

Struchkova, E. (2015). The formation of the methodological framework, principles, formsand tools of management of production activities, Business in the law, 1, 183-186. (in Russian). 


\title{
МЕТОДОЛОШКИ ПРИСТУП ПРОЦЕНИ ОРГАНИЗАЦИОНИХ РЕСУРСА ПРОИЗВОДНИХ АКТИВНОСТИ
}

\begin{abstract}
Alexander Miller
Извод

Циљ овог чланка је у решавању проблема везаних за развој теоријских и методолошких одредби код формирања процедура процене организационих ресурса производних активности.

Теоријски резултати ових истраживања су: унапређење концепта развоја организационих ресурса производних активности; идентификација утицаја организационих ресурса на произвдне активности; оправдање основних принципа формирања и система процене ефикасности употребе организационих ресурса.

Предложен је јединствени методолошки приступ, који омогућује комбиновање комплексности процене како количине најзначајнијих ресурса производних активности, тако и организационих ресурса; што значајно унапређује традиционалне системе менаџмента производних активности, који су засновани на идентификацији квантитативних параметара подсистема, њиховој процени, упоређењу и анализи.

Такође је предложено мишљење о процени вредности организационих ресурса. Оно је засновано на развоју производних активности и омогућује употребу развојних алата методолошког приступа за предвиђање утицаја квантитета најзначајнијих ресурса производних активности, као и организационих ресурса, на економске ефекте компанија.
\end{abstract}

Кључне речи: Организациони ресурси, методолошки приступ, производне активности, процена, индустрија 